\title{
Absolute Invalidity of Legal Actions and Trial of Relevant Lawsuits Pursuant to the Albanian Civil Procedural Legislation and Jurisprudence
}

\author{
Julejda Aliaj (Gërxhi) \\ Prof Asoc Dr , Department of Law, Faculty of Political-Legal Sciences \\ University “Aleksandër Moisiu" Durrës, Albania \\ Msc Enkelejda Haxhiraj
}

\begin{abstract}
Purpose of work: The Civil Code of the Republic of Albania provides no terms with regard to the validity of the legal action; however it sets forth the circumstances (legal facts) causing invalidity of legal actions. The purpose of this work is to analyze the essential elements of the legal action, which lack and ambiguity leads to action nullity. On the other hand, this work intends to present the interaction between material and procedural law and case-law with regard to the trial of those lawsuits dealing with absolute invalidity of legal actions. Research method: The methodology employed in this work relies on surveying and analyzing methods. Given its characteristics, this work is based on the qualitative methods to analyze the main elements of legal actions, which lack results in invalidity to nullity of such actions. The qualitative method includes the descriptive and interpretative method for trying lawsuits related to absolute invalidity of legal actions. Results: This work will give a clear picture of the concept of absolute invalidity of legal action and its trial pursuant to the Albanian procedural legislation and jurisprudence. Conclusions: Through this study we intend to make a deeper analysis on the absolute invalidity of legal actions, the causes of such invalidity and its trial pursuant to the procedural legislation and jurisprudence.
\end{abstract}

Keywords: legal action, absolute invalidity, effect, legislation, lawsuit, trial, jurisprudence.

\section{Introduction}

The structure of a legal transaction contains essential elements that are indispensable for such transaction to exist, and which lack of a single element only would render the legal transaction null and legally ineffective. Such elements are: subjects, expression of will, form of expression of will, object and legal cause.

In addition to such essential elements, a legal transaction may also contain other elements, which may be amendments established by the parties as provisions, without prejudice to the specific type of legal transaction, and which may restrict the normal content of the act.

Such elements are: condition, term, modus, penalty, etc.

These elements may exist or not in a legal transaction, but if they have been provided in its content, they will be considered as integral elements of the legal transaction. Missing or problematic essential elements of a legal transaction result in its absolute invalidity. Theoretically speaking, this kind of invalidity brings no legal effects from the moment the legal transaction has been carried out, which means that the parties engaged in such transaction cannot claim invalidity from the court, as it may be the court, on its own initiative, to rule for it. The parties may address to the court to regulate the effects arisen, and to achieve restitution, i.e. that the parties return to their previous state.

\section{The absolute invalidity of the legal transaction in terms of its essential elements and the jurisprudence}

Subjects. The legal transaction brings legal effects on the concerned subjects. So that the person, either natural or legal, may engage in legal transaction as a subject, and so that the legal transaction be legally valid and bring legal effects, it is 
necessary that the person have legal capacity (which is gained as of the moment of conception and live birth) and capacity to act (which is gained at 18 years of age and under the condition of mental capacity).

When a subject holds the power to express its will in carrying out a legal transaction and bring effects with regard to a specific situation, it is considered as a subject holding legitimacy. Referring to the legal situations, anperson may be allowed under the law to act in a legal relationship on behalf of another person so as to satisfy its own needs or those of third parties. When anperson acts on behalf of another person we refer to the representation, which may be legal - as it is the case of parents holding the legal representation of children - or voluntary representation, which is done through power of attorney.

Will: Article 79/1 of the civil code provides, "The legal transaction is the legal expression of a natural or legal person's will, which intends to establish, amend or extinguish civil rights or obligations". Referring to such provision in its material sense, the legal transaction is carried out through the wish or will of subjects. The element of will is expressively sanctioned in the provisions, which testifies the importance of such element in the commitment of legal transactions. The will is a dynamic element of the legal world; it is the essential element that gives life to the legal transaction. However, the will that is contained inside the subject brings no legal effects. Legal transactions require expression of the will and the external behavior of the person will technically be considered manifestation of its will.

The wish to commit the legal transaction represents the internal will of the person. It is a psychological phenomenon that may be perceived by the external behavior of the subject. Therefore, in the commitment of the legal transaction, the wish needs to be manifested in the external world so that the subjects of the civil-legal relation arising from the legal transaction be duly informed.

On the other side, the expression of the will must be lawful so that the transaction brings legal effects.

Legal transaction is carried out by the wish of a person, as well as by his free and full will. Often, legal transactions are determined as voluntary legal facts. However, the expression of the will brings no legal effects if it lack the due form and manner provided by the law. The expression of the will must be true and serious, the declaration must be presented seriously and directed toward the expressed goal, (for example a conversation between friends, although a declaration of will, brings no legal effects), otherwise, it may not be considered a lawful expression of a person's will, and consequently it may not bring legal effects. It is important that transactions of individuals are assessed by responsibility criteria, where each subject of the legal transaction is tied with the effects arising from the content of the transaction, always if such content results from conscious will. If we refer to the supra reasoning, according to which, the claim of the plaintiff against the defendant may extend up to the level of absolute invalidity in terms of the general principles on the vices of will, we say that legal transaction, among others, is considered absolutely invalid if the will of the parties is missing.

Form: Referring to article 79 of the Civil Code, so as to bring legal effects, the will needs to be expressed in a certain form. The general rule is the freedom of form: parties are free to express their will through the form they prefer. For example, the will may be expressed in tacit form, or through demonstrative means or ultimate transactions of the parties (e.g. the inheritor called to inheritance, although it has not been yet expressed its acceptance, acts as if it were the owner of the inheritance rights by selling an item of the inheritance or claiming the restitution of a loan). The will may be expressed in written words or signs. However, the principle of the freedom of form is not always applicable, as there are a number of legal transactions to be carried out in a certain form. Rules laying out requirements for the application of a certain form are often related to the seriousness of purpose. In solemn transactions (transactions that require the presence of the notary public), the form need to be ad substantium. In such cases, a specific form is required by law as an essential element of the legal transaction, as failure to abide by this specific form, would result in invalidity. For example, the sale and purchase of an immovable asset require that the written deed is made in the presence of the notary public. Article 83 of the civil code expressly provides, "The legal transaction made for the transfer of ownership of immovable assets and of the real rights over them, must be notarized and registered, otherwise it is not valid. The legal transaction that is not made in the form expressly required by law is not valid. In other cases, the legal transaction is valid, but it cannot be proved by witnesses".

In the everyday practice, the free and faultless will of the party in the legal transaction is thereby verified even by the fact that such transaction is made in the presence of the notary public through a notary deed, pursuant to the terms and conditions set forth in law no. 7829 dated 01 June 1995 "On Notaries", and the latter is a guarantor of the expression of the will pursuant to law. 
Cause. Cause is the social-economic function aimed by the concerned subjects. Cause appears as an objective interest and indispensability for the existence of the legal transaction. Cause is not to be confused with purpose, the impulse that impels the subject to carry out a legal transaction, which qualification requires the existence of a substantial cause for its legal existence.

Cause qualifies a legal transaction as:

Typical, i.e. provided by law

Atypical, i.e. entirely depending on the will of the subjects or

Mix

However, it is important to point out the difference between lawful cause and unlawful cause. Illicit transaction brings no desirable legal effects, whereas unlawful transaction brings undesirable legal effects, from which it arises the right to remedy the damage caused. This situation differentiates absolute invalidity from relative invalidity of legal transactions.

Absolute invalidity of a legal transaction, as one of the most serious forms of breaching the law, may be ascertained by the court ex officio throughout the trial.

This is the approach taken by the Unified Colleges in their unifying decision no. 13 dated 09 March 2006, expressly reading, "so that a legal transaction be considered absolutely invalid it is not necessary lodging any specific petition, either a lawsuit or a counter suit, given that this type of invalidity is ascertained independently of lodging a petition to the court. Absolute invalidity may be posed by any concerned party in the trial. The form it is posed may be even the counteraction, for the fact that an absolutely invalid legal transaction cannot be made valid with any successive transaction (Unifying decision no. 13/2006 of the Unified Colleges).

The Unified Colleges has taken some valuable approaches in the case-law, among which it is the following, "The legal transaction that is absolutely invalid brings no legal effects aimed by the parties; therefore, it has no legal power of a valid legal transaction. If, throughout the trial, the court ascertains that the legal transaction is absolutely invalid, it does not rule on declaring it invalid, but it only confirms its invalidity, and starting from this, it settles the dispute on the pertinent legal relationship. Absolute invalidity may be claimed by anyone concerned; it may be addressed to the other party of the legal transaction, as well as to any third party. Absolute invalidity may also be ascertained by the court ex officio, without being the concerned party to claim it, or against the wish of the concerned party. From the entirety of the provisions that regulate the institute of legal transactions' invalidity, it turns out that, when a legal transaction is absolutely invalid, even the legal transaction performed between one of the parties related to the invalid legal action and another person will be invalid, in the sense that it has no legal force" (Unifying decision no. 13/2006 of the Unified Colleges).

With reference to the above, an absolutely invalid legal transaction cannot be remedied; it cannot be made valid either at a later time or with other successive transactions. Given that absolute invalidity is one of the most serious forms of invalidity, in such case, the legal transaction is deemed to have never existed, i.e. to have never been performed. Independently of this invalidity of legal transactions, the latter may bring legal effects on their subjects, which need to be settled by the court, which ascertains absolute invalidity either on the claims of the trial parties or ex officio. Absolute invalidity of legal transactions is claimed pursuant to article 92/a of the civil code. Precisely, if a plaintiff claims that certain invalid legal transactions are in compliant with the law, but it fails to provide arguments and evidences on the cause of such in compliance, than the court will not try such claim of the plaintiff, and the case will be dismissed. In this sense, if the lawsuit claims confirmation of absolute invalidity of legal transactions without presenting any claim on the concrete legitimate interest of real nature that has been breached to the plaintiff due to such legal transactions committed, the court cannot accept such lawsuit.

In the same line goes even the unifying decision no. 5 dated 30 October 2012 of the Unified Colleges of the Supreme Court, providing, "One of the elements identifying the lawsuit and without which there can be no lawsuit, is its cause (causa petitionis). The cause of the lawsuit is the reason for claiming to the court, which contains the right and the fact opposing to such right. So that a lawsuit is tried by the court, it must contain not only the claim but also the cause. The claim for invalidity confirmation, without showing the right and the fact opposing to such right, is a lawsuit that, in the material sense, does not exist". 
Accordingly, referring to the reasoning of this decision, there can be no lawsuit without the cause. In such case, it is precisely the existence of: 1-the cause of the lawsuit, 2-the right and 3-the fact opposing to such right that constitute the breach of the plaintiff's rights, and that motivate him/her to address to the court, (article 32/a/b of the civil procedure code).

So, the reason for claiming, on which the lawsuit is based, must contain the material right on which it is grounded, and according to which the petition (petitium) must be determined, and the fact opposing to such right.

If confirmation only of absolute invalidity of a legal transaction is claimed in the petition of the lawsuit, without claiming remedy of effect, than such petition is defective, and as such it must lead the parties and the court to how to claim remedy of effects.

The court cannot rule extra petitionis on the invalidity of the legal transaction, except for cases of basic trials, for the reason that it is up to the parties rather than the court ex officio choose the petition of the lawsuit. Therefore the lawsuit cannot be grounded only on the confirmation of legal transaction invalidity. The fact also refers to the unifying decision no. 5 dated 30 October 2012 of the Supreme Court, which, for the purpose of unifying case-law, concludes:

A legal transaction that is invalid may be ascertained by the court, even ex-officio, without being claimed by the concerned party, or even against the will (wish) of such party. So that a legal transaction be considered absolutely invalid it is not necessary lodging any specific petition, either a lawsuit or a countersuit, given that this type of invalidity is ascertained independently of lodging a petition to the court.

\section{Conclusions:}

Claims to ascertain absolute invalidity of a legal transaction cannot be lodged as a single claim; rather, they should be lodged during the basic trial of a case, or at leas as a claim associated with the remedy of effects produced from its enforcement. The effects produced from the enforcement (fulfillment) of an absolutely invalid legal transaction are settled on petition of the trail parties only, and if it is the court to ascertain ex officio the invalidity of a legal transaction, it settles only those effects that have been claimed with the lawsuit, without ruling on the effects not specifically claimed by the parties.

Moreover, it should be proven the existence of a real situation of breaching; in other words, a basic lawsuit should be lodged to defend the subjective right infringed, so that the absolute invalidity of legal transactions may be questioned during the trial, even though incidental.

So the petition of the plaintiff must contain what he/she is claiming to obtain from the rule of law, while an absolutely invalid legal transaction is null, being considered as never existing, and therefore it cannot be claimed merely its invalidity.

\section{Literature}

[1] Civil Code of the Republic of Albania 1994 (with relevant amendments); AlbJuris, Tirana 2017

[2] Civil Procedure Code of the Republic of Albania (with relevant amendments); AlbJuris, Tirana 2017

[3] Publication of Official Center for Publications, November 2009 "Summary of European Court of Human Rights judgments against Albania"

[4] Official Gazette no. extra 86, dated 28.02.2013 "Supreme Court case-law through civil, administrative, and criminal decisions", publication of Supreme Court, 2014

[5] Galgano Francesco. Private Law 1. Ownership, Tirana 2003

[6] Unifying Decision no. 13/2006 of the Unified Colleges

[7] Decision no. 27 dated 26.10.2010 of the Constitutional Court

[8] Unifying Decision no. 5/2012 of the Unified Colleges of the Supreme Court

[9] Unifying Decision no. 7/2012 of the Unified Colleges of the Supreme Court 